\title{
PROTECTIVE EFFECT OF BROCCOLI AND FERULIC ACID ON IMIDACLOPRID-INDUCED HEPATOTOXICITY IN RAT
}

\author{
Mahgoub M. Ahmed ${ }^{1}$ and Sawsan A. Nasr ${ }^{2}$ \\ ${ }^{1}$ Molecular Drug Evaluation Department and ${ }^{2}$ Physiology \\ Department,National Organization for Drug Control and \\ Research (NODCAR), Giza 12553, Egypt
}

Received 18/2/2015- Accepted 16/3/2015

\begin{abstract}
Imidacloprid may induce oxidative stress leading to generate free radicals and alternate oxygen free radical scavenging enzyme system. This study aims to investigate the hepatoprotective effect of broccoli water extract and ferulic acid on imidacloprid induced oxidative stress and DNA damage in male albino rats. Rats were co-treated with broccoli water extract $(200 \mathrm{mg} / \mathrm{kg})$ or ferulic acid $(20 \mathrm{mg} / \mathrm{kg})$ with imidacloprid $(80 \mathrm{mg} / \mathrm{kg})$ orally for 28 days. The results revealed that imidacloprid induced high serum levels of aspartate aminotransferase (AST), alanine aminotransferase (ALT) and alkaline phosphatase (ALP). However, administration of broccoli and ferulic acid reduced these parameters. Broccoli and ferulic acid significantly $(P<0.05)$ attenuated the imidacloprid-induced increases in lipid peroxidation (LPO), tumor necroses factor $\alpha$ (TNF- $\alpha$ ) and nitric oxide (NO) contents and meyloperoxidase (MPO), glutathione-S-transferase (GST) and glucose-6-phosphate dehydrogenase (G6PD) activities. Imidacloprid decreased reduced glutathione (GSH) while co-treatment with broccoli and ferulic acid significantly $(P<0.05)$ improved the level of GSH. DNA damage as assessed by comet assay was increased in imidacloprid-treated group. However, DNA damage was decreased in
\end{abstract}

* Correspondence Author (e mail: mahgouba3@gmail.com) 
broccoli and ferulic acid treated groups. The possible mechanism of broccoli and ferulic acid extract on imidacloprid might be due to decreasing oxidative stress (LPO, NO and DNA damage) and increasing GSH content. Thus, broccoli and ferulic acid was suggested to protected rat's liver against imidacloprid-induced oxidative stress and DNA damage in liver.

Keywords: broccoli, ferulic acid, imidacloprid, DNA damage, oxidative stress, GSH

\section{INTRODUCTION}

Imidacloprid is newer nicotine analogue systemic insecticide (Kammon et al., 2010). Imidacloprid exposure leads to marked biochemical, histopathological and ultrastructural changes in various organs so imidacloprid was found to be a potent hepato, nephro and neurotoxic agent (Soujanya and Rajendra, 2013). Induction of oxidative stress is one of mechanisms of the action of many pesticides (Kapoor, et al., 2010) and imidacloprid is one of them (Toor $\boldsymbol{e t}$ al., 2013). Imidacloprid was found to induce DNA damage in a doserelated manner in earthworms as well as to increase the frequency of adducts in pesticide-treated calf thymus DNA, indicating agentinduced genotoxicity (Zang et al., 2000).

Broccoli is a cruciferous vegetable, a member of the cabbage. It is densely packed with vitamins, especially vitamins $\mathrm{A}$ and $\mathrm{C}$ and minerals that promote health. It has broad antibiotic propertiesincluding nematocidal, antimicrobial, antiprotozoal and insecticidal activities (Subramanian and Gowry, 2011). In addition broccoli contains the flavonols quercetin and kaempferol, the carotenoids $\beta$ carotene and lutein, and the glucosinolates that may reduce risk of certain types of cancer (Podsedek, 2007). Recent researches suggested that both dietary broccoli and the individual components sulforaphane and indole-3-carbinol might offer protection from cardiovascular, neurodegenerative diseases and inflammation (Hwang and Lim, 2014). Ferulic acid is a natural antioxidant phenolic acid, found especially in wheat, corn, rice, tomatoes, spinach and cabbage (Anselmi et al., 2007). 
Moreover, ferulic acid is an effective antihepatotoxic agent without side effects and may be a good candidate for a natural hepatoprotective agent (Rukkumani et al., 2004).

Therefore, the present study was aimed to elucidate the hepatoprotective role of broccoli and ferulic acid against imidacloprid-induced oxidative stress and DNA damage in rats.

\section{Chemicals}

\section{MATERIALS AND METHODS}

Ferulic acid, GSH and thiobarbituric acid were purchased from SigmaAldrich Co. (St. Louis, MO, USA). Imidacloprid 20\% suspension obtained from First Kim for fertilizer and Agricultural pesticides Co., Egypt. TNF- $\alpha$ ELISA assay kit was obtained from eBioscience. All other chemicals and reagents used were of analytical grade.

\section{Plant extracts}

Broccoli purchased from Experimental Station of Medicinal Plants, Faculty of Pharmacy, Cairo University was dried, powdered before extraction. One hundred grams of broccoli were extracted by percolation with water. The aqueous extract was filtered then freeze dried. Water extract was used for further study.

Total phenolics, Total flavonoids and Total isothiocyanates contents Total phenolics, total flavonoids and total isothiocyanates contents in the broccoli extract were determined according to Claudia et al. (2008), Zhishen et al. (1999) and Zhang et al. (1992), respectively.

\section{Animals and experimental design}

Male albino rats, weighing 180-200 g, were obtained from animal house of National Organization for Drug Control \& Research (NODCAR), Egypt. The animals were kept under standard laboratory conditions of light/dark cycle $(12 / 12 \mathrm{~h})$ and temperature $\left(25 \pm 2^{\circ} \mathrm{C}\right)$. They were provided with a nutritionally adequate standard laboratory diet. Animals were divided equally into six groups, 6 animals each.

-Group 1 served as the control.

-Group 2 was treated with imidacloprid at the dose of $80 \mathrm{mg} / \mathrm{kg}$ bodyweight (Soujanya et al., 2014). 
-Group 3 was treated with ferulic acid at the dose of $20 \mathrm{mg} / \mathrm{kg}$ body weight (Sudheer et al., 2008).

-Group 4 was treated with broccoli extract at the rate of $200 \mathrm{mg} / \mathrm{kg}$ body weight.

-Group 5 was treated with both imidacloprid $(80 \mathrm{mg} / \mathrm{kg})$ and ferulic acid $(20 \mathrm{mg} / \mathrm{kg})$.

-Group 6 was treated with both imidacloprid $(80 \mathrm{mg} / \mathrm{kg})$ and broccoli extract $(200 \mathrm{mg} / \mathrm{kg})$.

These drugs were administered by oral gavage every day consequently for 28 days. At the end of the experiment, rats were sacrificed by cervical dislocation and blood was collected without any anticoagulant. The serum separated was used for studying the serum biochemical profile ALT, AST and ALP using commercially reagents. The livers were removed and washed in cold isotonic saline. The livers were homogenized in $50 \mathrm{mM}$ phosphate buffer $(\mathrm{pH}$ 7) using an electronic homogenizer to prepare $10 \% \mathrm{w} / \mathrm{v}$ homogenate. The homogenates were centrifuged at $3000 \mathrm{rpm}$ for $10 \mathrm{~min}$ at $4^{\circ} \mathrm{C}$. The supernatant was used for the estimation of LPO (measured as MDA) (Buege and Aust, 1978), G6PD (Zaheer et al., 1965), GSH (Ellman, 1959), NO (Wang et al, 2002, using Griess reaction), MPO (Olsen and Little, 1983) and GST (Habig et al., 1974). TNF- $\alpha$ level was determined using ELISA kit. Protein content in the mitochondrial fraction was estimated by the method of Lowry et al. (1951). Comet assay was used to estimate DNA damage. Ethidium Bromide-stained DNA (using a 40X objective) were observed on a fluorescent microscope. Komet 5 image analysis software developed by Kinetic Imaging, Ltd. (Liverpool, UK) linked to a CCD camera were used to assess the quantitative and qualitative extent of DNA damage in the liver by measuring tail length, tail DNA \% and extent tail moment.

\section{Statistical analyses}

Statistical analyses were performed with SPSS software and were calculated using one-way ANOVA followed by the least significant differences (LSD). $P<0.05$ was considered to indicate a statistically significant result. 


\section{RESULTS}

As shown in Table 1, broccoli extract had markedly contents of total phenolics $(45.5 \pm 2.7)$, total flavonoids $(11.3 \pm 0.9)$ and total isothiocyanate $(2.9 \pm 0.2)$.

We monitored hepatic dysfunction caused by imidacloprid toxicity by measuring AST, ALT and ALP liver enzymes. Fig. 1 shows that serum analysis revealed a significant $(P<0.05)$ increase in mean values of AST, ALT and ALP, by the administration of imidacloprid in rat when compared with control group. Significant decrement $(P<0.05)$ appeared in AST, ALT and ALP activities in groups treated with broccoli extracts and ferulic acid co-administration compared with the imidacloprid.

Table 1: Total phenolics, total flavonoids and total isothiocyanate contents in Broccoli water extract

\begin{tabular}{|l|l|}
\hline Contents & Broccoli water extract \\
\hline Total phenolics $(G A E \mathbf{m g} / 100 \mathrm{~g} \mathrm{dw})$ & $45.5 \pm 2.7$ \\
\hline Total flavonoids $(C A E \mathrm{mg} / 100 \mathrm{~g} \mathrm{dw})$ & $11.3 \pm 0.9$ \\
\hline Total isothiocyanate $(S P \mu m o l / g d w)$ & $\mathbf{2 . 9} \pm 0.2$ \\
\hline
\end{tabular}

Data are expressed as mean \pm S.E. of three replicates, GAE; Gallic acid equivalent, CAE; Catechin equivalent, SP; sulforaphane

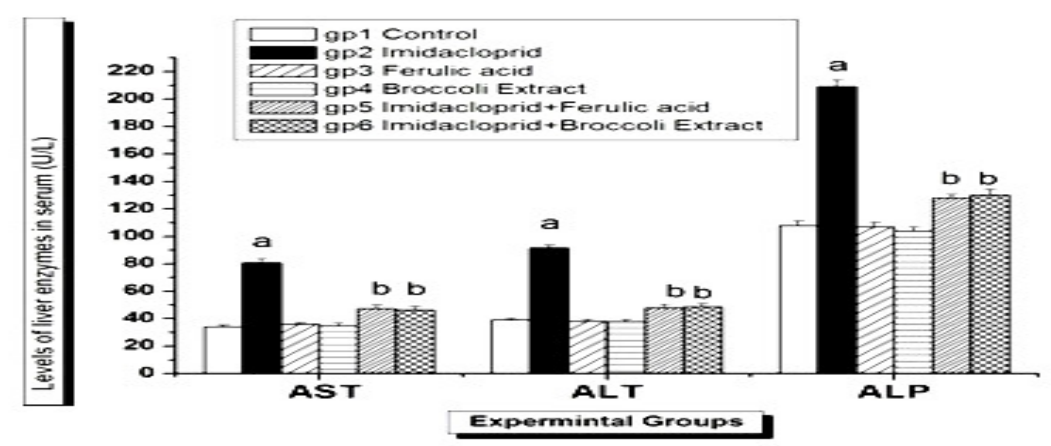

Fig 1: Effect of ferulic acid and broccoli extract on imidacloprid-induced enhancement of serum AST, ALT and ALP in rats. Bars are expressed as mean \pm S.E. of 6 rats per group. ${ }^{a}$ Significant different from Control group at $P<0.05,{ }^{b}$ Significant different from imidacloprid-treated group at $P<0.05$. 
Co-administration of ferulic acid or broccoli significantly $(P<0.05)$ reversed the above values when compared with imidacloprid group. GSH and LPO levels, GST and G6PD activities were increased in imidacloprid group when compared with the control group and these changes were ameliorated by supplementation of either ferulic acid or broccoli extract when compared with imidacloprid group.

Table 2: Effects of ferulic acid and broccoli on GSH and LPO contents and GST and G6PD activities following imidacloprid administration

\begin{tabular}{|l|l|l|l|l|}
\hline Groups & $\begin{array}{l}\text { GSH } \\
\text { (umol } \\
\text { GSH/mg } \\
\text { protein) }\end{array}$ & $\begin{array}{l}\text { LPO } \\
\text { (nmol } \\
\text { MDA/mg } \\
\text { protein) }\end{array}$ & $\begin{array}{l}\text { GST } \\
\text { (U/mg } \\
\text { protein) }\end{array}$ & $\begin{array}{l}\text { G6PD } \\
\text { (nmol } \\
\text { NADPH/min/m } \\
\text { g protein) }\end{array}$ \\
\hline Group 1 & $16.42 \pm 0.71$ & $0.95 \pm 0.09$ & $6.26 \pm 0.06$ & $313.50 \pm 10.78$ \\
\hline Group 2 & $7.36 \pm 0.54^{\mathrm{a}}$ & $3.23 \pm 0.11^{\mathrm{a}}$ & $11.34 \pm 0.04^{\mathrm{a}}$ & $884.24 \pm 20.34^{\mathrm{a}}$ \\
\hline Group 3 & $18.29 \pm 0.84$ & $0.89 \pm 0.07$ & $6.19 \pm 0.15$ & $337.44 \pm 17.51$ \\
\hline Group 4 & $16.96 \pm 1.26$ & $0.97 \pm 0.05$ & $6.24 \pm 0.12$ & $341.14 \pm 17.60$ \\
\hline Group 5 & $12.34 \pm 0.67^{\mathrm{b}}$ & $1.82 \pm 0.10^{\mathrm{b}}$ & $8.02 \pm 0.12^{\mathrm{b}}$ & $385.85 \pm 30.50^{\mathrm{b}}$ \\
\hline Group 6 & $13.99 \pm 0.65^{\mathrm{b}}$ & $1.11 \pm 0.13^{\mathrm{b}}$ & $8.59 \pm 0.08^{\mathrm{b}}$ & $434.08 \pm 21.57^{\mathrm{b}}$ \\
\hline
\end{tabular}

Data are expressed as mean \pm S.E. of 6 rats per group. ${ }^{a}$ Significant different from Control group at $P<0.05,{ }^{b}$ Significant different from imidaclopridtreated group at $P<0.05$.

However, no significant changes in hepatic GSH and LPO levels, GST and G6PD activities in both ferulic acid and broccoli extract when compared with control group.

Hepatic levels of NO, MPO and TNF $\alpha$ were markedly increased $(P<0.05)$ after the administration of imidacloprid when compared with control group. These effects were opposed significantly $(P<0.05)$ when co-administered with either ferulic acid or broccoli extract when compared with imidacloprid group. However, the levels of hepatic NO, MPO and TNF $\alpha$ were not significantly altered after ferulic acid or brocclli extract administration when compared with control group (Table 3). 
Table 3: Effects of ferulic acid and broccoli on TNF- $\alpha$ and NO contents and MPO activity following imidacloprid administration

\begin{tabular}{|c|c|c|c|}
\hline Groups & 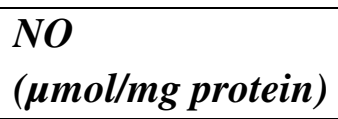 & $\begin{array}{l}\text { MPO } \\
\text { (U/mg protein) }\end{array}$ & $\begin{array}{l}T N F-\alpha \\
\text { (pg/mg protein) }\end{array}$ \\
\hline Group 1 & $7.77 \pm 0.95$ & $8.88 \pm 0.26$ & $12.54 \pm 0.46$ \\
\hline Group 2 & $16.33 \pm 0.62^{\mathrm{a}}$ & $15.40 \pm 0.11^{\mathrm{a}}$ & $28.16 \pm 0.59^{a}$ \\
\hline Group 3 & $6.78 \pm 0.13$ & $8.69 \pm 0.06$ & $10.89 \pm 0.32$ \\
\hline Group 4 & $7.36 \pm 1.00$ & $10.78 \pm 0.78$ & $11.66 \pm 0.24$ \\
\hline Group 5 & $11.46 \pm 0.25^{b}$ & $12.30 \pm 0.07^{b}$ & $16.74 \pm 0.38^{b}$ \\
\hline Group 6 & $11.96 \pm 0.21^{b}$ & $12.09 \pm 0.28^{b}$ & $12.37 \pm 0.56^{b}$ \\
\hline
\end{tabular}

Data are expressed as mean \pm S.E.M. of 6 rats per group. ${ }^{a}$ Significant different from Control group at $P<0.05,{ }^{b}$ Significant different from imidacloprid-treated group at $P<0.05$.

Hepatic DNA damage in imidacloprid-treated rats which demonstrated by comet assay were shown in Table 4 and Fig 2 . DNA damage was indicated by significant $(P<0.05)$ increase in the tail length, tail DNA \% and extent tail moment in imidacloprid-treated rats when compared with control group. These changes were improved significantly $(P<0.05)$ after co-administration of ferulic acid or broccoli extract when compared with imidacloprid group.

\section{DISCUSSION}

The widespread use of pesticides in public health and agriculture programs has caused severe environmental pollution and health hazards, including cases of severe acute and chronic human poisoning (Abdollahi et al., 2004). In our study serum AST, ALT and ALP activities were significantly increased in imidacloprid intoxicated group. These results suggest that administration of this insecticide cause destructive changes in hepatic cells leading to the release of the enzymes from the cytoplasm into the blood circulation after rupture of the plasma membrane and cellular damage (Bansal et al., 2005). 
Table 4: Effect of ferulic acid and broccoli on imidacloprid-induced hepatic DNA damage (tail Length, tail DNA \% and extent tail Moment).

\begin{tabular}{|l|l|l|l|}
\hline Groups & $\begin{array}{l}\text { Tail length } \\
(\boldsymbol{\mu m})\end{array}$ & Tail DNA \% & $\begin{array}{l}\text { Extent tail moment } \\
\text { (arbitrary unit })\end{array}$ \\
\hline Group 1 & $1.59 \pm 0.07$ & $1.70 \pm 0.09$ & $2.72 \pm 0.27$ \\
\hline Group 2 & $6.69 \pm 0.76^{\mathrm{a}}$ & $6.53 \pm 0.30^{\mathrm{a}}$ & $43.89 \pm 5.86^{\mathrm{a}}$ \\
\hline Group 3 & $1.67 \pm 0.08$ & $1.73 \pm 0.07$ & $2.88 \pm 0.03$ \\
\hline Group 4 & $1.80 \pm 0.14$ & $1.77 \pm 0.10$ & $3.18 \pm 0.26$ \\
\hline Group 5 & $4.67 \pm 0.18^{\mathrm{b}}$ & $5.14 \pm 0.35^{\mathrm{b}}$ & $24.11 \pm 2.53^{\mathrm{b}}$ \\
\hline Group 6 & $4.32 \pm 0.20^{\mathrm{b}}$ & $4.56 \pm 0.23^{\mathrm{b}}$ & $19.82 \pm 2.12^{\mathrm{b}}$ \\
\hline
\end{tabular}

Data are expressed as mean \pm S.E.M. of 6 rats per group. ${ }^{a}$ Significant different from Control group at $P<0.05,{ }^{b}$ Significant different from imidacloprid-treated group at $P<0.05$.
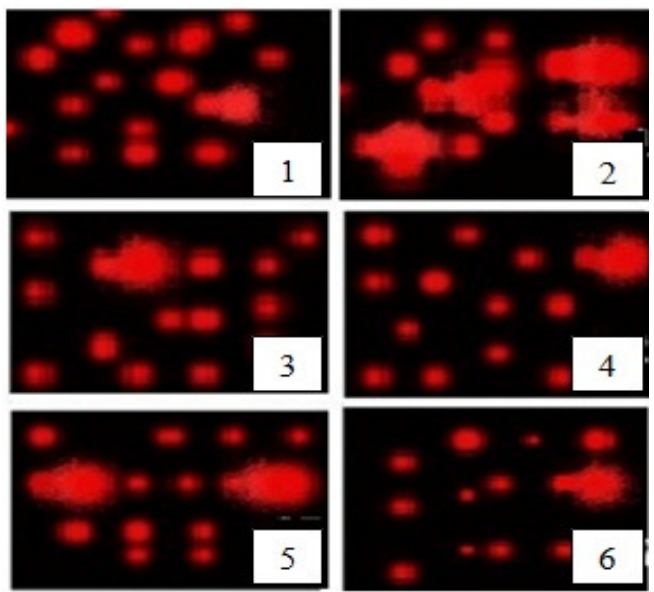

Fig 2: Images of cells analyzed by comet assay in the hepatocytes of rat liver. (1) Control group (Undamaged), (2) Imidacloprid-intoxicated rats group (Strongly damaged), (4) and (6) Ferulic acid and Broccoli extract groups (Undamaged) and (3) and (5) Ferulic acid or Broccoli + Imidacloprid intoxicated rats group (slightly damaged). 8 
Pesticides can induce oxidative stress by generation of free radicals that might cause lipid peroxidation, alternations in membrane fluidity, DNA damage and finally carcinogenic effects (Singh $\boldsymbol{e t}$ al., 2006). In this study, the observed increase in LPO and a concomitant depletion in GSH level, suggests that the increased LPO may be a consequence of depleted GSH stores.

Increased level of LPO in hepatic tissue in the present study supports the results of Giray et al. (2001) who have reported an increased level of LPO in hepatic tissues of rats administered cypermethrin.

In addition, we observed significant enhanced activity of GST, which is understandable in the light of depressed GSH levels. GST is a detoxifying enzyme that catalyzes the conjugation of a variety of electrophillic substrates to the thiol group of GSH, producing less toxic forms (Hayes et al., 2005). Singh et al. (2006) reported that pesticides; cypermethrin, dimethoate and chlorpyrifos treatment caused a significant increase in GST activity. This induction may be due to the GSH and glutathione dependent enzymes system that provide major protection against the toxic agents. G6PD is the key enzyme of the pentose phosphate pathway that is responsible for the generation of NADPH (required for conversion of oxidized glutathione to the reduced form) and essential for the protection of cells against oxidative damage (Marks, 1961). In the present study, G6PD increased significantly in liver after imidacloprid treatment.

In the present study, imidacloprid administration caused an elevated production in NO and TNF- $\alpha$ levels in liver. Similarly, Duzguner and Erdogan (2012) have reported that imidacloprid causes oxidative stress and inflammation in central nervous system and rats' liver. Beside NO and TNF- $\alpha$, MPO is another well-known inflammatory enzyme, highly expressed by activated neutrophils, characterised by powerful prooxidative and pro-inflammatory properties (Valentina et al., 2008). The significant increase in MPO activity observed in the present study, may be attributed to increased neutrophils production due to imidacloprid induced inflammation evidenced by elevated production in NO and TNF- $\alpha$ levels in liver. Neutrophils can be activated by cytokines, such 
as TNF- $\alpha$ and IL- 8 and are then mobilized to the site of inflammation (Hallett and Lloyds, 1995).

In the present study, the levels of tail length, extent tail moment and \% DNA in tail were significantly increased in imidacloprid-treated group when compared with control group. Several reactive mutagenic and genotoxic lipid peroxidation products in particular malondialdehyde (MDA) and 4-hydroxy-2-nonenal (HNE) have been identified to bind to DNA and to damage it (Eder $\boldsymbol{e t}$ al., 2006). Moreover, reactive oxygen species produced from imidacloprid can attack DNA, producing a distinctive pattern of DNA alterations (Kovacic and Somanathan 2008).

In this study, the broccoli extract had $45.5 \pm 2.7 \mathrm{mg} / 100 \mathrm{~g}$ total phenolics, $11.3 \pm 0.9 \mathrm{mg} / 100$ total flavonoids and $2.9 \pm 0.2 \mu \mathrm{mol} / \mathrm{g}$ total isothiocyanate. So the observed preventive activity of broccoli extract in our study may be suggested due to the presence of these compounds.

The antioxidant activity of phenolics and flavonoids, which act as reducing agents and hydrogen donors, has been studied (Williams $\boldsymbol{e t}$ al., 2004). The present study revealed that co-treatment of imidacloprid with either broccoli extract or ferulic acid caused a significant decrease in serum levels of AST, ALT, and ALP, also it significantly restored the hepatic level of GSH, GST, activities near normal and concomitantly decreased LPO levels and decrease DNA damage when compared to imidacloprid treated group. Wargovich (1999) reported that cruciferous vegetables namely cabbage, cauliflower and broccoli are rich in anticarcinogens, glucosinolates, flavonoids, vitamins, and mineral nutrients which are potent modulators of xenobiotic metabolising enzymes that protect DNA from damage (Moreno et al., 2006). In particular, isothiocyanates and indole derivatives, including sulforaphane, phenylethyl isothiocyanate, and indole-3- carbinol, are reported to have antioxidant and anticancer activities (Stoews, 1995). A possible mechanism of reduced activities of the tested enzymes and hepatoprotective effect of broccoli extract may be attributed to its antioxidant effect of the phenolic and flavonoid compounds. Broccoli possesses hepatoprotective capacity and may have potential therapeutic 10 
value in the treatment of some liver disorders probably by its antioxidative effects on hepatocytes, due to flavonoids and sulfurated compounds (Al-Howiriny, 2008).

Ferulic acid is an effective anti-hepatotoxic agent without side effects and may be a good candidate for a natural hepatoprotective agent (Rukkumani et al., 2004). Ferulic acid exhibits many physiological functions including antioxidant, and anti-inflammatory (Ou and Kwok 2004). In the current study, co-administration of broccoli and ferrulic acid successfully decreased the levels of NO, TNF- $\alpha$, and MPO activity in the imidacloprid-treated rats. Broccoli is anti-inflammatory due to their high content of polyphenols and flavonoids (Wood et al., 1982). Moreover, Hwang and Lim (2014) have reported that production of the pro-inflammatory cytokines TNF- $\alpha$, IL- $1 \beta$, and IL- 6 was also inhibited by broccoli in a dose-dependent manner.

In conclusion, the present study concluded that the water extract of broccoli and ferulic acid had hepatoprotective effects against imidaclopride-induced oxidative stress and DNA damage in rats. The high protective effect of the broccoli extract on imidacloprid appeared to be attributed to its high total phenolics, total flavonoids and total isothiocyanate contents.

\section{REFERENCES}

Abdollahi M., Ranjbar A., Shadnia S., Nikfar S. and Rezaie A. (2004): Pesticides and oxidative stress: a review. Med. Sci. Monit. 10: 141-147.

Al-Howiriny T. (2008): Evaluation of hepatoprotective activity of broccoli 'Brassica oleracea' in rats. Hungarian Medical Journal 2: 145165.

Anselmi C., Bernardi F., Centinin M., Gaggelli E., Gaggelli N., Valensin D. and Valensin G. (2007): Interaction of ferulic and derivatives with human erythrocytes monitored by pulse field gradient NMR diffusion and NMR relaxation studies. Chem. Phys. Lipids 134: 109-117.

Bansal A.K., Bansal M., Soni G. and Bhatnagar D. (2005): Protective 
role of Vitamin E pre-treatment on N-nitrosodiethylamine induced oxidative stress in rat liver. Chem. Biol. Interact.; 156: 101-111.

Buege J.A. and Aust S.D. (1978): Microsomal lipid peroxidation. Methods in Enzymology 52: 302-310.

Claudia A., Graciela E.F. and Rosana F. (2008): Total polyphenols content and antioxidant capacity of commercially available tea (Camellia sinesis) in Argentina. Journal of agriculture food chemistry 56:9225-9229.

Duzguner V. and Erdogan S. (2012): Chronic exposure to imidacloprid induces inflammation and oxidative stress in the liver \& central nervous system of rats. Pestic. Biochem. Physiol.104 (1): 58-64.

Eder E., Wacker M., Lutz U., Nair J., Fang X., Batsch H., Beland F.A., Schlatter J. and Lutz W.K. (2006): Oxidative stress related DNA adducts in the liver of female rats fed with sunfower, rapeseed, olive or coconut oil supplemented diets. Chem Biol Interact. 159: 81-89.

Ellman G.L. (1959): Tissue sulfhydryl groups. Arch Biochem Biophys. 82: 70-77.

Giray B., Gurbay A. and Hincal F. (2001): Cypermethrin-induced oxidative stress in rat brain and liver is prevented by vitamin $\mathrm{E}$ allopurinol. Toxicol. Lett. 118: 139-146.

Habig W.R., Pbst M.J. and Jakpoly W.B. (1974): Glutathione transferase. A first enzymatic step in mercaturic acid formation. J. Biol. Chem. 249: 7130-7139.

Hallett M.B. and Lloyds D. (1995): Neutrophil priming: the cellular signals that say 'amber' but not 'green'. Immunol. Today 16:264-268.

Hayes J.D., Flanagan J.U. and Jowsey I.R. (2005): Glutathione transferases. Annu. Rev. Pharmacol. Toxicol. 45: 51-88.

Hwang J.H. and Lim S.B. (2014): Antioxidant and Anti-inflammatory Activities of Broccoli Florets in LPS-stimulated RAW 264.7 Cells. Prev. Nutr. Food Sci. 19 (2): 89-97.

Kammon A.M., Brar R.S., Banga H.S. and Sodhi S. (2010): Pathobiochemical studies on hepatotoxicity and nephrotoxicity on exposure to chlorpyrifos and imidacloprid in layer chickens. Veterinarski Arhiv. 80 (5): 663-672.

Kapoor U., Kumar M.S., Bhardwaj S. and Prasad L.S. (2010): Effect of Imidacloprid on antioxidant enzymes and lipid peroxidation in female rats to derive its NO observed effect level (Noel). J. Toxicol. Sci. 35(4): 577-581. 
Kovacic P. and Somanathan R. (2008): Unifying mechanism for eye toxicity, Electron transfer, reactive oxygen species, antioxidant benefits, cell Signaling and cell Membranes. Cell Membrane Free Radical Research 2: 56-69.

Lowry O.H., Roseborough N.J., Farr A.L., and Randall R.L. (1951): Protein measurement with phenol reagent. Journal of Biological Chemistry. 193 (1): 265-275.

Marks P.A. (1961): Enzymes of the pentose phosphate pathway. Methods Med. Res. 9: 24-35.

Moreno D.A., Carvaja M., López-Berenguer C. and García-Viguera N. (2006): Chemical and biological characterisation of nutraceutical compounds of broccoli. J Pharm Biomed Anal. 41: 1508-1522.

Olsen R.L. and Little C. (1983): Purification and some properties of myeloperoxidase and eosinophil peroxidase from human blood. Biochem. J. 209 (3): 781-787.

Ou S. and Kwok K. C. (2004): Ferulic acid: pharmaceutical functions, preparation and applications in foods. J Sci. Food and Agric. 84 (11): 1261-1269.

Podsedek A. (2007): Natural antioxidants and antioxidant capacity of Brassica vegetables: a review. LWT 40: 1-11.

Rukkumani R., Aruna K., Suresh Varma P., Padmanabhan L. and Menon V. (2004): Hepatoprotective role of ferulic acid: a dosedependent study. J Med Food. 7(4):456-461.

Singh N. P., McCoy M.T., Tice R.R., Schneider E.L. (1988): A simple technique for quantitation of low levels of DNA damage in individual cells. Exp. Cell Res. 175: 184-191.

Singh M., Sandhir R. and Kiran R. (2006): Erythrocyte antioxidant enzymes in toxicological evaluation of commonly used organophosphate pesticides. Ind. Exp. Biol. 44: 580-583.

Soujanya S., Lakshman M., Anand K.A. and Gopala A. (2014): Evaluation of the protective role of vitamin $\mathrm{C}$ in imidacloprid-induced hepatotoxicity in male Albino rats. Journal of Natural Science, Biology and Medicine 4 (1): 63-67.

Soujanya S. and Rajendra K. (2013): Imidacloprid induced toxicity and oxidative stress. Global Research Analysis 6(2): 224-225.

Stoews G.S. (1995): Bioactive organosulfur phytochemicals in Brassica oleracea vegetables, a review. Food Chem Toxico. 133: 537-543.

Subramanian V. and Gowry S (2011) : Antitumor Activity and 
Antioxidant Role of Brassica oleracea Italica against ehrlich ascites Carcinoma In Swiss Albino Mice. RJPBCS 2 (3): 275-285.

Sudheer A.R., Muthukumaran S., Devipriya N., Devaraj H., and Menon V.P. (2008): Influence of ferulic acid on nicotine induced lipid peroxidation, DNA damage and inflammation in experimental rats as compared to N-acetylcysteine. Toxicology 243: 317-329.

Toor H.K., Sangha G.K. and Khera K.S. (2013): Imidacloprid-induced histological and biochemical alterations in liver of female albino rats. Pestic. Biochem. Physiol. 105(1):1-4.

Valentina L., Ilaria D., Francesca G., and Luigi M.B. (2008): Review Article Myeloperoxidase: A New Biomarker of Inflammation in Ischemic Heart Disease and Acute Coronary Syndromes.Mediators of Inflammation. Mediators Inflamm. 2008: 2007-2011.

Wang C.C., Huang Y.J., Chen L.G., Lee L.T. and Wang L.L. (2002): Inducible nitric oxide synthase inhibitors of Chinese herbs III. Rheum palmaturn. Planta Medica 68 (10): 869-874.

Wargovich, M.J. (1999): Nutrition and cancer: the herbal revolution. Curr. Opin. Gastroenterol.; 15: 177-180.

Williams R.J., Spencer J.P. and Rice-Evans C. (2004): Flavonoids: antioxidants or signalling molecules? Free Radic. Biol. Med. 36: 838849.

Wood A.W., Huang M.T., Chang and R.L. (1982): Inhibition of the mutagenicity of bay-region diol epoxides of polycyclic aromatic hydrocarbons by naturally occurring plant phenols: Exceptional activity of ellagic acid. Proceedings of the National Academy of Sciences of the USA 79: 5513-5517.

Zaheer N., Tiwari K.K. and Krishnan P.S. (1965): Expouser and solubilization of hepatic mitochondrial shunt dehydrogenases. Archive of Biochemistry and Biophysics 109: 646-648.

Zang Y., Zhong Y., Lou Y. and Kong Z.M. (2000): Genotoxicity of two novel pesticides for the earthworm, Eisenia fetida, Environ. Pollut. 108: 271-278.

Zhang Y., Cho C.G., Posner G.H. and Talalay P. (1992): Spectroscopic quantitation of organic isothiocyanates by cyclocondensation with vicinal dithiols. Anal Biochem.205(1):100-107. Zhishen J., Mengcheng T. and Jianming W. (1999): The determination of flavonoid contents in mulberry and their scavenging effects on superoxide radicals. Food Chem. 64:555-559. 


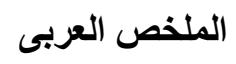

تقييم التأثير الواقي لكلا من البروكلي و حض الفريوليك ضد مبيد /مباكلوبيريد المسبب

$$
\text { للسمية الكبلية في الجرزان الفربئ }
$$

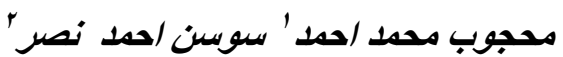

'شعبة التقييم الدو ائى الجزيئى و بَثعبة الفسيولوجى الهيئة القومية للرقابة و البحوث الدو ائية

ان الهدف من هذه الدر اسة هو دراسة التأثير الو اقي لكلا من المستخلص المائي للبروكلي و

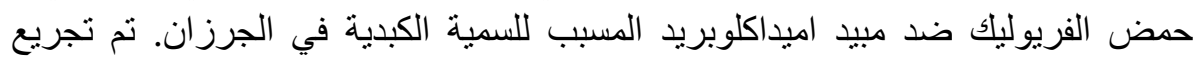

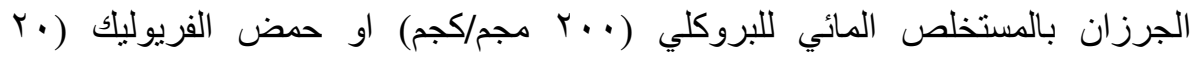

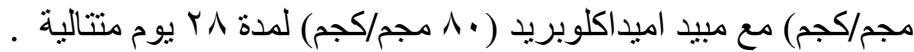

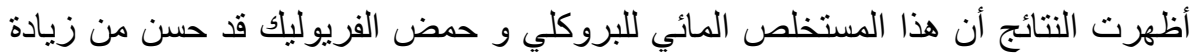

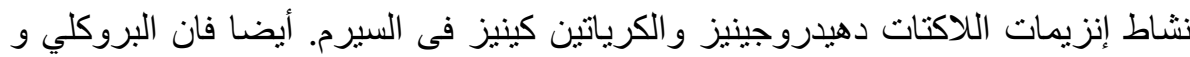
حمض الفريوليك قد حسن من محتوى كلا من أكسدة الليبيدات و أكسيد النيتريك و و

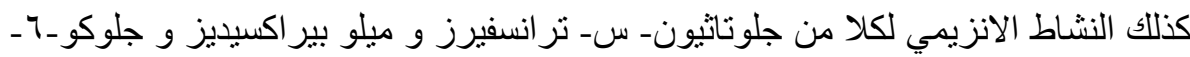

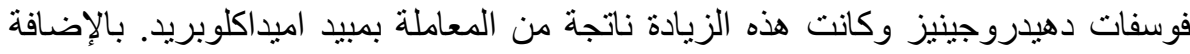

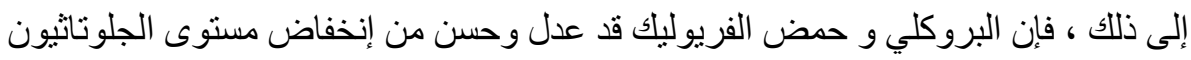

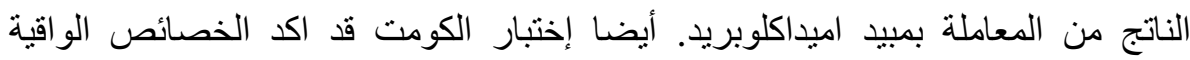

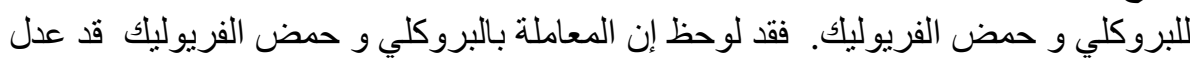

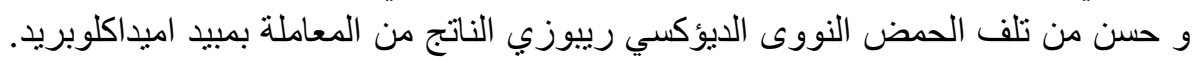

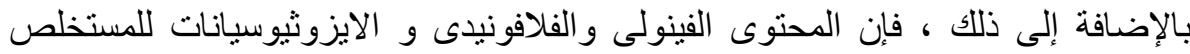

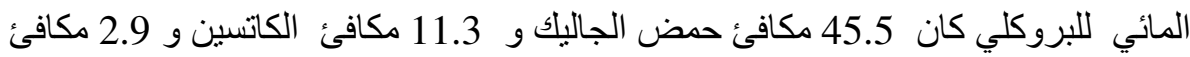

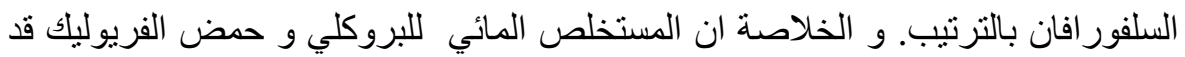
استطاع حماية الكبد من السمية الناجمة من المعاملة بمبيد الاميداكلوبريد. 